Provided for non-commercial research and education use. Not for reproduction, distribution or commercial use.

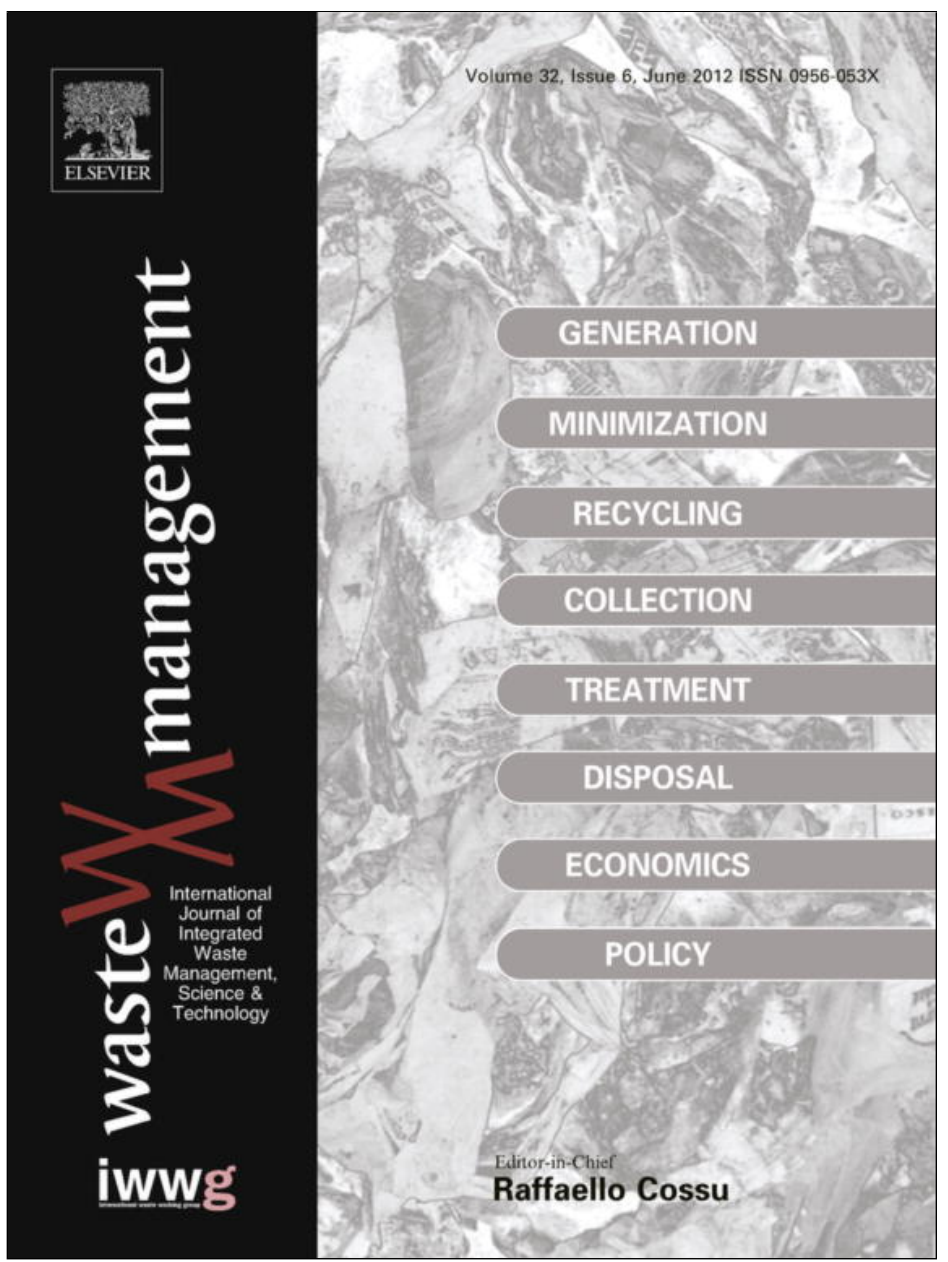

This article appeared in a journal published by Elsevier. The attached copy is furnished to the author for internal non-commercial research and education use, including for instruction at the authors institution and sharing with colleagues.

Other uses, including reproduction and distribution, or selling or licensing copies, or posting to personal, institutional or third party websites are prohibited.

In most cases authors are permitted to post their version of the article (e.g. in Word or Tex form) to their personal website or institutional repository. Authors requiring further information regarding Elsevier's archiving and manuscript policies are encouraged to visit:

http://www.elsevier.com/copyright 


\title{
Environmental effects of using clay bricks produced with sewage sludge: Leachability and toxicity studies
}

\author{
Joan A. Cusidóa ${ }^{\mathrm{a}}$, Lázaro V. Cremades ${ }^{\mathrm{b}, *}$ \\ ${ }^{a}$ Department of Physics and Nuclear Engineering, Universitat Politècnica de Catalunya, 08190 Sant Cugat del Vallès, Barcelona, Spain \\ ${ }^{\mathrm{b}}$ Department of Engineering Design, Universitat Politècnica de Catalunya, 08028 Barcelona, Spain
}

\section{A R T I C L E I N F O}

\section{Article history:}

Received 3 June 2011

Accepted 28 December 2011

Available online 20 January 2012

\section{Keywords:}

Sewage sludge

Ceramic matrix

Leachability

Toxicity

Clay bricks

Sanitary risk

\begin{abstract}
A B S T R A C T
Use of sewage sludge from wastewater treatment plants as a raw material for making clay bricks has been analyzed to be an option to dumping sludges into landfills. This alternative has been shown feasible and interesting due to the high rate of use of ceramic materials in the building sector. However, it meets with some environmental issues and some prejudices on the part of users.

This work shows some leachability and toxicity tests (outgassing and offgassing) which demonstrate the environmental compatibility of these ceramic products to be used as building materials and even in deconstruction of the building once its useful life is ended.
\end{abstract}

(C) 2012 Elsevier Ltd. All rights reserved.

\section{Introduction}

Disposal of sewage sludges from wastewater treatment plants (WWTP) is a serious global environmental issue. During the last 20 years, the most developed countries have been converting urban sludge into a resource such as: (a) fertilizer in agriculture, (b) industrial chemicals (i.e. cements), (c) energy, and/or (d) material for building. Depending on the composition and characteristics of the urban sludge, treatment is applied for a given resource use. Before the sludge can be converted into a resource, first it is important to solve the problem of its high moisture contents. There is no guarantee that the most efficient, most energy saving, and most economical sludge wastewater treatment technology will not develop a secondary environmental pollution. Transforming sludges as a raw material for making clay bricks may be one relevant solution to this problem if the final product achieves good environmental performances (Fig. 1).

Incorporating sewage sludges or incineration ashes to ceramic matrices has been proposed and researched since the eighties of the last century (Alleman and Berman, 1984; Ferreira et al., 1999; Lin and Weng, 2001; Weng et al., 2003; Liew et al., 2004; Montero et al., 2009). These authors have shown the feasibility of that industrial process. However, some sectors of public opinion are against to put in practice that process, because it claims that on one hand such a process is like a concealed incineration or

\footnotetext{
* Corresponding author. Tel.: +34 934011750, fax: +34 934016646

E-mail address: lazaro.cremades@upc.edu (L.V. Cremades).
}

pyrolysis that would emit hazardous air pollutants, and on the other hand the products from that process would not be innocuous for the health of users. Actually, the toxicity and health related issues are well documented and are relatively easy to find in the literature, for instance, REACH (2006) or WHO (2011).

In summary, there is a public concern about the sanitary safety of buildings built with these materials, since it is thought that it means to place toxic and hazardous wastes directly into houses. There is then necessary to achieve a deep and suitable environmental assessment of both industrial process and final products.

This paper aims to analyze the leachability and toxicity of ceramic products made with different types of municipal sewage sludges and paper industry sludges, in order to show the harmlessness of these materials during their life cycle. Emission of gases during their production has been already studied in other works (Cusidó et al., 2003).

Leachates are the eluates formed by reaction, draining or filtration of materials contained in the waste. They have some substances in solution or in suspension that can be infiltrated into ground giving rise to soil and/or underground water pollution issues, representing potential risks to environment. In our case, leachates from ceramic materials (clay bricks) made with sewage sludges are basically heavy metals that were present in the waste (or in the clay). Organic compounds from sludges are fully destroyed during firing at the ceramic production, and then do not appear in leachates (Weng et al., 2003).

From a general point of view, most important heavy metals which can damage human health are: arsenic (As, cancerigen), 


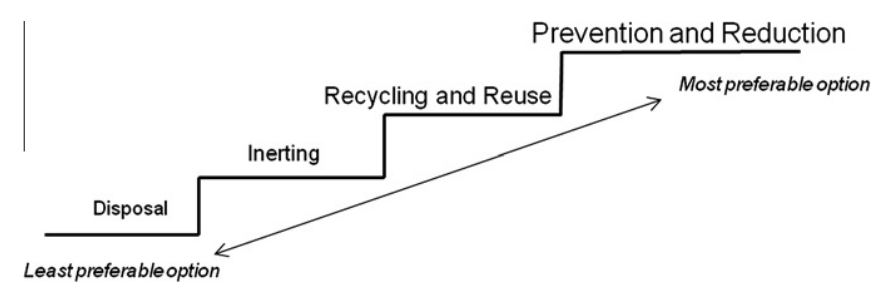

Fig. 1. Hierarchy of pollution prevention. The use of sewage sludge for making ceramic material is considered the second step: recycling and reuse.

cadmium ( $\mathrm{Cd}$, probably cancerigen, teratogenic and embryotoxic), chromium $(\mathrm{Cr}$, cancerigen and probably mutagenic), lead $(\mathrm{Pb}$, probably teratogenic), mercurium (Hg, teratogenic), and nickel (Ni, probably cancerigen and teratogenic). Apart from leachates, it is necessary to know the composition of unhealthy particles and gas emissions that could be released from ceramic products by means of rigorous degasification and toxicity studies. With these studies, we can assess the effective inertization of sewage sludges into ceramic matrix.

\section{Experimental procedure}

\subsection{Products analyzed}

Samples tested consisted of ceramic pieces made with different WWTP sewage sludges: physico-chemical, biological and from paper industry. These pieces were prepared by mixing variable percentages of clays, sludges, and eventually forest waste (sawdust), and then by extruding the mixture, according to the information presented in Table 4. Some of these pieces included coating ceramics made with spray-dried raw sludges from physico-chemical WWTP (dry route) (Fig. 2). Procedure for manufacturing is explained in Cusidó et al. (2003) and Devant et al. (2011).

Chemical composition of inorganic compounds in the sludges and clays tested is presented in Table 1 . In our case, organic compounds were not a concern due to their total thermal destruction. General procedure for obtaining the ceramic pieces consists of the following stages: formation of the "green" (or wet) mixture, extrusion, drying, and thermal treatment up to $1050^{\circ} \mathrm{C}$, as usual in the

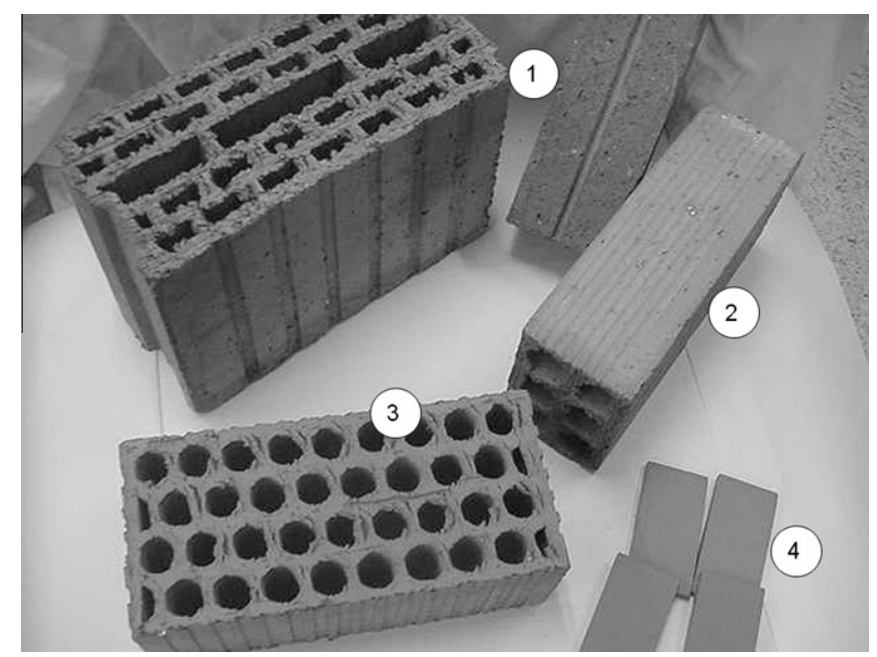

Fig. 2. Ceramic materials for building produced in industrial tests containing different percentages and types of sewage sludges that are under investigation: (1) ceramic block and clay brick made from biological treatment sludges and shredded forest residues (sawdust); (2) clay brick produced with physical-chemical treatment sludges; (3) structural ceramics made from paper industry sludge; (4) tiles obtained with atomized raw sludges from physical-chemical treatment. industrial production of clay bricks and tiles (in this last case, the piece is formed by compressing dry dust from atomized sludge).

At this temperature, organic matter is totally destroyed and is responsible for the high porosity of the microstructure (Fig. 3 ). This porosity, although affects the mechanical resistance, gives the ceramic piece interesting properties such as low weight, and thermal and acoustic insulation. A description of the process for producing ceramic materials with sludges can be found in Alleman and Berman (1984), Almeida et al. (1997), Cusidó et al. (2003), and others.

\subsection{Leaching/extraction test related to building materials}

Development of leaching studies has issued a high scientific controversy about which should be the right methodology, especially as far as methods of chemical extraction of leachates are concerned. In this sense, there is a wide international literature and research (Wiebusch et al., 1998) and even some EU Directives have been dictated with the aim of harmonizing the methodologies related with building materials (Van der Sloot, 2005).

In the present study, we have followed the norm NEN 7345 from the Netherlands Tank Leaching Test (NEN 7345, 1993). This norm is expressly dedicated to building materials and largely applied in Netherlands and EU, in general.

To carry out the tests, three samples of $8 \mathrm{~cm}$ long were prepared to which volume, surface area and mass were measured, in each case. The samples were put into distilled water and the concentration of inorganic compounds was measured at several time intervals. Procedure was as follows.

\subsubsection{Preparation of samples}

Each piece was introduced into a polyethylene container and covered with distilled water at $\mathrm{pH}$ fitted to 4 by adding nitric acid which was used as extractant agent, according to NEN 7345. This norm is more severe than the more recent NEN 7375 (2004) in which the diffusion test is conducted with $\mathrm{pH}$ neutral instead of acidified water. In total, there were 12 sample recipients, three of them containing a blank ( $100 \%$ clay ceramic piece). Volume of extractant agent in each recipient should have to be 5 times the volume of the sample, and the sample had to be covered by a layer of not less than $5 \mathrm{~cm}$ high.

For each sample, eight extractions were done. The sample was left with a given number of days, such as indicated in Table 2, without agitation. The extractant agent was changed at every further sampling.

Leachate obtained from each extraction was filtered through a $0.45 \mathrm{~mm}$ filter, its $\mathrm{pH}$ was corrected with nitric acid, and chemical elements were analyzed following their appropriate technique:

- Heavy metals at $\mathrm{pH}=2$.

- Fluor at $\mathrm{pH}=5-6$.

- Cianures and ions: without pH correction.

\subsubsection{Measurement and calculation}

Elements measured and techniques used were those described in Table 3.

Eq. (1) was used to compute leachability of each pollutant at the $i$-th extraction:

$E_{i}=\frac{\left(C_{i}-C_{o}\right) V}{1000 A}$

where $E_{\mathrm{i}}$, leachability of a pollutant at the $i$-th extraction $\left(\mathrm{mg} \mathrm{m}^{-2}\right)$; $C_{\mathrm{i}}$, pollutant concentration at the $i$-th extraction $\left(\mathrm{mg} \mathrm{L}^{-1}\right) ; C_{0}$, pollutant concentration in the blank $\left(\mathrm{mgL}^{-1}\right) ; V$, volume of extractant agent $(\mathrm{L}) ; A$, surface area of the sample $\left(\mathrm{m}^{2}\right)$. After eight extractions, 
Table 1

Qualitative mineralogical analysis of crystalline phases of clay and sludge used as raw materials for the production of ceramic pieces. Relative concentration of mineral species are represented by asterisks $\left({ }^{*}<^{* *}<* * *<* * *\right)$.

\begin{tabular}{|c|c|c|c|c|c|c|c|}
\hline Mineral species & Stoichiometric formula & $\begin{array}{l}\text { Clay (El } \\
\text { Papiol) }\end{array}$ & $\begin{array}{l}\text { Clay } \\
\text { (Alcoletge) }\end{array}$ & $\begin{array}{l}\text { Sludge from } \\
\text { biological treatment } \\
\text { (Gavà) }\end{array}$ & $\begin{array}{l}\text { Sludge from biological } \\
\text { treatment (Martorell) }\end{array}$ & $\begin{array}{l}\text { Sludge from physico- } \\
\text { chemical treatment }\end{array}$ & $\begin{array}{l}\text { Sludge from } \\
\text { paper industry }\end{array}$ \\
\hline Quartz & $\mathrm{SiO}_{2}$ & $* * * *$ & $* * * *$ & $* * *$ & $* * *$ & $* * *$ & $* * *$ \\
\hline Calcite & $\mathrm{CaCO}_{3}$ & $* *$ & $* * * *$ & $* * * *$ & $* * * *$ & $* * * *$ & $* * * *$ \\
\hline Dolomite & $\mathrm{CaMg}\left(\mathrm{CO}_{3}\right)_{2}$ & $*$ & $*$ & $* *$ & $*$ & $*$ & - \\
\hline Feldspar & $(\mathrm{Na}, \mathrm{K}) \mathrm{AlSi}_{3} \mathrm{O}_{8}$ & $*$ & $*$ & - & - & $*$ & - \\
\hline Muscovite & $\mathrm{KAl}_{2}\left(\mathrm{Si}_{3} \mathrm{Al}\right) \mathrm{O}_{10}(\mathrm{OH}, \mathrm{F})_{2}$ & $* *$ & $* *$ & * & $*$ & $* *$ & - \\
\hline Chlorite & $(\mathrm{Mg}, \mathrm{Fe})_{6}(\mathrm{SiAl})_{4} \mathrm{O}_{10}(\mathrm{OH})_{8}$ & ** & ** & * & * & $*$ & - \\
\hline Montmorillonite & $\mathrm{Ca}_{0,4}\left(\mathrm{Al}_{3,33} \mathrm{Mg}_{0,67}\right) \mathrm{Si}_{8} \mathrm{O}_{10}\left(\mathrm{OH}_{4}\right)$ & ** & - & - & - & * & - \\
\hline Hematite & $\mathrm{Fe}_{2} \mathrm{O}_{3}$ & * & - & - & - & $* * *$ & - \\
\hline Goetite & $\mathrm{Fe}(\mathrm{OH}) \mathrm{O}$ & - & $*$ & - & - & - & - \\
\hline Albite & $\mathrm{NaAlSi}_{3} \mathrm{O}_{8}$ & - & - & $*$ & ** & $*$ & - \\
\hline Microcline & $\mathrm{KAISi}_{3} \mathrm{O}_{8}$ & - & - & * & $*$ & * & - \\
\hline Halite & $\mathrm{NaCl}$ & - & - & * & - & * & - \\
\hline Anhidrite & $\mathrm{CaSO}_{4}$ & - & - & - & * & $*$ & - \\
\hline Kaolinite & $\mathrm{Al}_{2} \mathrm{Si}_{2} \mathrm{O}_{5}(\mathrm{OH})_{4}$ & - & - & - & - & - & $*$ \\
\hline Cellulose & $\left(\mathrm{C}_{6} \mathrm{H}_{10} \mathrm{O}_{5}\right)_{\mathrm{x}}$ & - & - & - & - & - & ** \\
\hline Sulfates & $\mathrm{SO}_{4}^{2-}$ & - & - & - & - & - & $*$ \\
\hline
\end{tabular}

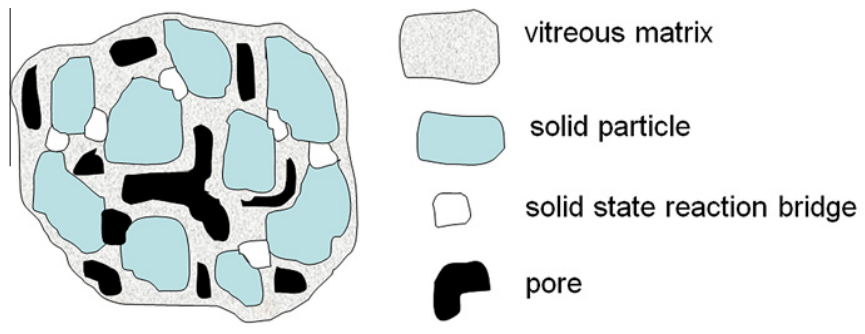

Fig. 3. Rough sketch of the microstructure of ceramic materials that incorporate sewage sludges in their raw materials. In black the porosity caused by the therma destruction of organic matter. The vitreous phase embeds mostly heavy metals contained in both sludges and clays (macro-encapsulation mechanism).

\begin{tabular}{|c|c|}
\hline $\begin{array}{l}\text { Extraction } \\
\text { No. }\end{array}$ & $\begin{array}{l}\text { Cumulative time } \\
\text { (days) }\end{array}$ \\
\hline 1 & 0.25 \\
\hline 2 & 1 \\
\hline 3 & 2.25 \\
\hline 4 & 4 \\
\hline 5 & 9 \\
\hline 6 & 16 \\
\hline 7 & 36 \\
\hline 8 & 64 \\
\hline
\end{tabular}

Eq. (2) was used to compute the leachability, $E$, for each pollutant in the sample:

$E=\sum_{i=1}^{8} E_{i}$

\subsubsection{Evaluation}

According to the norm NEN 7345, building materials are classified in relation with the leachability test in two categories: (a) materials without any environmental restriction $\left(<U_{1}\right)$, and (b) materials having a restricted use $\left(<U_{2}\right)$. Materials whose total leachability is comprised between $U_{1}$ and $U_{2}$ values do not have any environmental restriction as far as their use in building, but the pollutant that exceeds the $U_{1}$ threshold should be removed at
Table 3

Experimental techniques used in the leaching test (NEN 7345).

\begin{tabular}{ll}
\hline Compounds & Technique used \\
\hline Cyanides & $\begin{array}{l}\text { Absorption spectrophotometry, after distillation to calculate } \\
\text { total cyanides }\end{array}$ \\
$\begin{array}{c}\text { Heavy } \\
\text { metals }\end{array}$ & Atomic emission spectrometry by inductively coupled plasma \\
$\begin{array}{l}\text { Fluor } \\
\text { Ions }\end{array}$ & $\begin{array}{l}\text { Selective electrode } \\
\text { Ion chromatography }\end{array}$ \\
\hline
\end{tabular}

the end of the product life (dismantling). Finally, materials whose leachability thresholds are above $U_{2}$ should have a restricted use in building and dismantling.

\subsection{Outgassing and offgassing tests for toxicity evaluation}

Outgassing and offgassing tests aim to determine the gases and particles emitted by the material tested in general (ESA PSS01-729, 1991; ESA PSS-01-702, 1994). They are accelerated tests to cover a simulated time equivalent of 10 years to prove the absence of potential health risks, in our case applied to users of houses built with materials made from sewage sludge and/or other wastes. These tests are used to allow the presence of such materials in manned spacecrafts. We have chosen them as the most rigorous testing for our samples.

The following tests were performed:

- Outgassing test ESA PSS-01-702 (1994): It allows to ascertain the outgassing properties of materials obtaining data about percentage of weight loss of material (WLM) as well as volatile condensed matter (VCM). It is performed by creating an overpressure in the interior of a camera specially equipped for this purpose.

- Offgassing test ESA PSS-01-729 (1991): It determines the amount of carbon monoxide (CO) and total organic compounds (TOC) emitted by the material, if their presence is detectable (concentrations above $10 \mathrm{mg} \mathrm{g}^{-1}$ of material tested).

Both tests have been approved by the European Space Agency (ESA) and are equivalent to those used by NASA.

To carry out these tests we used samples of $5 \mathrm{~cm}$ in length for different percentages of sludge in the ceramic matrix (in triplicate). 
Table 4

Leaching tests conducted in several ceramic materials after 8 extractions. Leachate concentrations are expressed as mg m ${ }^{-2}$. "n.d." $=$ no detectable concentration from the measuring equipment.

\begin{tabular}{|c|c|c|c|c|c|c|c|c|c|c|c|c|c|c|c|c|c|c|}
\hline Ceramic material & As & $\mathrm{Ba}$ & $\mathrm{Cd}$ & Co & $\mathrm{Cr}$ & $\mathrm{Cu}$ & Mo & $\mathrm{Ni}$ & $\mathrm{Pb}$ & $\mathrm{Sb}$ & Se & Sn & $\mathrm{V}$ & $\mathrm{Zn}$ & $\mathrm{Br}^{-}$ & $\mathrm{Cl}^{-}$ & $\mathrm{F}^{-}$ & $\mathrm{SO}_{4}^{2-}$ \\
\hline \multicolumn{19}{|c|}{ Bricks with physical-chemical sludge (clay A) } \\
\hline$(0 \%)$ & n.d. & n.d. & n.d. & n.d. & n.d. & n.d. & n.d. & n.d. & n.d. & n.d. & n.d. & n.d. & 77 & n.d. & 215 & n.d. & 212 & 3471 \\
\hline$(20 \%)$ & n.d. & n.d. & n.d. & n.d. & n.d. & n.d. & n.d. & n.d. & n.d. & n.d. & n.d. & n.d. & 75 & 5 & n.d. & 243 & n.d. & 3182 \\
\hline$(40 \%)$ & n.d. & n.d. & n.d. & n.d. & n.d. & n.d. & 7 & n.d. & n.d. & n.d. & n.d. & n.d. & 111 & n.d. & n.d. & n.d. & n.d. & n.d. \\
\hline$(60 \%)$ & n.d. & n.d. & n.d. & n.d. & n.d. & n.d. & 8 & n.d. & n.d. & n.d. & n.d. & n.d. & 105 & 4 & n.d. & n.d. & n.d. & n.d. \\
\hline \multicolumn{19}{|c|}{ Coating ceramic with spray-dried raw sludge (clay A) } \\
\hline$(0 \%)$ & n.d. & n.d. & n.d. & n.d. & n.d. & n.d. & n.d. & n.d. & n.d. & n.d. & n.d. & n.d. & 72 & n.d. & n.d. & n.d. & n.d. & n.d. \\
\hline$(5 \%)$ & n.d. & n.d. & n.d. & n.d. & 3 & n.d. & n.d. & n.d. & n.d. & n.d. & n.d. & n.d. & 69 & n.d. & n.d. & n.d. & n.d. & n.d. \\
\hline$(10 \%)$ & n.d. & n.d. & n.d. & n.d. & 7 & n.d. & n.d. & n.d. & n.d. & n.d. & n.d. & n.d. & 71 & n.d. & n.d. & n.d. & n.d. & n.d. \\
\hline$(15 \%)$ & n.d. & 1 & n.d. & n.d. & 15 & n.d. & n.d. & n.d. & n.d. & n.d. & n.d. & n.d. & 69 & n.d. & n.d. & n.d. & n.d. & n.d. \\
\hline$(20 \%)$ & n.d. & 2 & n.d. & n.d. & 15 & n.d. & n.d. & n.d. & n.d. & n.d. & n.d. & n.d. & 67 & n.d. & 667 & n.d. & n.d. & n.d. \\
\hline \multicolumn{19}{|c|}{ Ceramic material made of ternary mixtures of sludge, forest residue and clay A. Sludge came from a biological WWTP } \\
\hline$(0 \%, 0 \%, 100 \%)$ & n.d. & n.d. & n.d. & n.d. & n.d. & n.d. & n.d. & n.d. & n.d. & n.d. & n.d. & n.d. & 76 & n.d. & n.d. & n.d. & n.d. & n.d. \\
\hline$(15 \%, 5 \%, 80 \%)$ & n.d. & 2 & n.d. & n.d. & $10 \pm 1$ & n.d. & n.d. & n.d. & n.d. & 0.3 & n.d. & n.d. & 79 & n.d. & n.d. & n.d. & $95 \pm 92$ & $20,000 \pm 1000$ \\
\hline \multicolumn{19}{|c|}{ Ceramic material made of ternary mixtures of sludge (A or B), forest residue and clay A fired at $980{ }^{\circ} \mathrm{C}$. Sludge came from a biological WWTP } \\
\hline$(0 \%, 0 \%, 100 \%)$ & n.d. & n.d. & n.d. & n.d. & n.d. & n.d. & n.d. & n.d. & n.d. & n.d. & n.d. & n.d. & 76 & n.d. & n.d. & n.d. & n.d. & n.d. \\
\hline$(15 \%, 5 \%, 80 \%)$ Sludge A & n.d. & 2 & n.d. & n.d. & $10 \pm 1$ & n.d. & n.d. & n.d. & n.d. & 0.3 & n.d. & n.d. & 79 & n.d. & n.d. & n.d. & $95 \pm 92$ & $20,000 \pm 1000$ \\
\hline$(15 \%, 5 \%, 80 \%)$ Sludge B & n.d. & n.d. & n.d. & n.d. & n.d. & n.d. & n.d. & n.d. & n.d. & n.d. & n.d. & n.d. & 4 & n.d. & n.d. & n.d. & n.d. & n.d. \\
\hline \multicolumn{19}{|c|}{ Ceramic material made of ternary mixtures of sludge (A or B), forest residue and clay B fired at $980{ }^{\circ} \mathrm{C}$. Sludge came from a biological WWTP } \\
\hline$(0 \%, 0 \%, 100 \%)$ & n.d. & n.d. & n.d. & n.d. & 2 & n.d. & n.d. & n.d. & n.d. & n.d. & n.d. & n.d. & 30 & n.d. & n.d. & n.d. & n.d. & $2000 \pm 300$ \\
\hline$(15 \%, 5 \%, 80 \%)$ Sludge A & n.d. & n.d. & n.d. & n.d. & 46 & n.d. & n.d. & n.d. & n.d. & n.d. & n.d. & n.d. & 23 & n.d. & n.d. & n.d. & n.d. & $19,000 \pm 1000$ \\
\hline$(15 \%, 5 \%, 80 \%)$ Sludge B & n.d. & n.d. & n.d. & n.d. & 15 & n.d. & 5 & n.d. & n.d. & n.d. & n.d. & n.d. & 52 & n.d. & n.d. & n.d. & n.d. & n.d. \\
\hline \multicolumn{19}{|c|}{ Ceramic material with paper industry sludge (clay A) } \\
\hline$(0 \%)$ & n.d. & n.d. & n.d. & n.d. & n.d. & n.d. & n.d. & n.d. & n.d. & n.d. & n.d. & n.d. & 78 & n.d. & 215 & n.d. & 212 & 3471 \\
\hline$(15 \%)$ & n.d. & n.d. & n.d. & n.d. & n.d. & n.d. & n.d. & n.d. & n.d. & n.d. & n.d. & n.d. & 52 & n.d. & n.d. & n.d. & n.d. & n.d. \\
\hline \multicolumn{19}{|c|}{ Leaching limits set by the Netherlands Tank Leaching Test (NEN 7345) } \\
\hline $\mathrm{U} 1$ & 40 & 600 & 1 & 25 & 150 & 50 & 15 & 50 & 100 & 3.5 & 1.5 & 25 & 250 & 200 & 25 & 20,000 & 1500 & 20,000 \\
\hline $\mathrm{U} 2$ & 300 & 4500 & 7 & 200 & 950 & 350 & 95 & 350 & 800 & 25 & 9.5 & 200 & 1500 & 1500 & 200 & 150,000 & 9500 & 150,000 \\
\hline
\end{tabular}

The experimental methodology according to the norms was as follows:

\subsubsection{ESA PSS-01-702}

Samples were cut using a minimum size of $2 \times 2 \mathrm{~cm}^{2}$, according to the capacity of sample holders. Their geometry was approximately cubic. The minimum weight of each sample had to be $5 \mathrm{~g}$. Samples were inserted within a special chamber with two collector plates. The extraction was done by subjecting the sample to a vacuum of $10^{-3} \mathrm{~Pa}$, and keeping a temperature of $125^{\circ} \mathrm{C}$ for $24 \mathrm{~h}$. Gases that emerge from the sample were deposited by condensing them on a chrome-plated aluminum collector plate constantly maintained at $25^{\circ} \mathrm{C}$.

After $24 \mathrm{~h}$, the system was vented with dry nitrogen or inert gas to a pressure between 104 and $208 \mathrm{~Pa}$. As the system cooled to $50{ }^{\circ} \mathrm{C}$, pressure continued to decrease to reach the ambient air pressure.

Once removed the specimens, they were allowed to dry for $30 \mathrm{~min}$ and collector plates for $1 \mathrm{~h}$. After this process, both were kept in a closet or temperature- and humidity-controlled room $\left(20{ }^{\circ} \mathrm{C}\right.$ and $\left.65 \%\right)$ for $24 \mathrm{~h}$. The plates, after this process, were analyzed by infrared spectroscopy to get the concentrations of contaminants condensed.

\subsubsection{ESA PSS-01-729}

Samples were prepared by cutting them into pieces of $1.25 \pm 0.2 \mathrm{~cm}$ thick and an apparent total area of $50 \pm 5 \mathrm{~cm}^{2}$ per liter of the working chamber. First, the chamber was purged with dry hydrogen or helium, at $80^{\circ} \mathrm{C}$ and vacuum of less than $1.3 \mathrm{~Pa}$ for $24 \mathrm{~h}$. Then, the samples were introduced into that sealed chamber by keeping the following working conditions: $50{ }^{\circ} \mathrm{C}$, $1 \mathrm{~atm}$ and air with $25 \%$ oxygen. These conditions were maintained for $72 \mathrm{~h}$. Finally, the chamber was connected to the sampling equipment.
After, the chamber was allowed to cool to room temperature and samples were taken from air to be subsequently analyzed.

\section{Results}

Table 4 shows the leaching balances of ceramic pieces made with different kinds of sludge, clay and eventually forest waste (sawdust). It also shows those for pieces made of $100 \%$ clay for comparison purposes. In the case of binary mixtures using sewage sludges from physico-chemical WWTP, it can be observed that all concentrations $\left(\mathrm{mg} \mathrm{m}^{-2}\right)$ are far below the $U_{1}$ limits, except for vanadium $(V)$ whose concentration slightly increases with the contents of sludge. In any case it would be a clay brick without environmental restrictions for use in construction.

In the case of ceramic pieces generated by ternary mixtures, these mixtures consisted of sewage sludges from biological WWTP, forest waste (sawdust), and clay. We have used two different types of sludges (from two WWTP: Martorell and Gavà) and two types of clays (from two sites: El Papiol and Alcoletge). The results indicate values far below the $U_{1}$ limits, with the exception of vanadium $(\mathrm{V})$, and chromium $(\mathrm{Cr})$ in the case of clay B (Alcoletge). This suggests that the raw material is responsible for the presence of chromium although in a very small amount. Similarly, sulfates concentration in this case approaches the limit $U_{1}\left(25,000 \mathrm{mg} \mathrm{kg}^{-1}\right)$, whose presence is due to sludge regardless of its origin.

Leaching test of ceramic pieces made with sludges from paper industry (15\%) highlights the presence of vanadium $(\mathrm{V})$, brome $(\mathrm{Br})$ and fluor $(\mathrm{F})$, but values are below their $U_{1}$ limits.

Table 4 also shows the leaching balance of coating ceramics obtained by mixing clay with atomized powder of primary sludges from physico-chemical WWTP. It is worth noting that, since the sludge is dry, concentrations are much higher than in previous cases. It should be emphasized the presence of brome $(\mathrm{Br})$ and vanadium $(\mathrm{V})$, but it is not attributable to atomized sludge since ceramics made of pure clay already produces that result. Anyway, 
Table 5

Outgassing and offgassing tests applied to the ceramic pieces made from different types of sludge.

\begin{tabular}{|c|c|c|c|c|}
\hline \multirow[t]{2}{*}{ \% sludge } & \multicolumn{2}{|c|}{ Outgassing test } & \multicolumn{2}{|c|}{ Offgassing test } \\
\hline & WLM (\%) & VCM (\%) & $\mathrm{CO}\left(\mu \mathrm{gg}^{-1}\right)$ & $\mathrm{TOC}\left(\mu \mathrm{gg}^{-1}\right)$ \\
\hline \multicolumn{5}{|c|}{ Ceramic material made with sludge from physico-chemical WWTP } \\
\hline 0 & 0.054 & 0 & $<25$ & $<100$ \\
\hline 20 & 0.097 & 0.001 & $<25$ & $<100$ \\
\hline 40 & 0.1 & 0.001 & $<25$ & $<100$ \\
\hline 60 & 0.093 & 0.001 & $<25$ & $<100$ \\
\hline \multicolumn{5}{|c|}{ Ceramic material made with spray-dried raw sludge from physico-chemical WWTP } \\
\hline 0 & 0.054 & 0 & $<25$ & $<100$ \\
\hline 20 & 0.012 & 0.001 & $<25$ & $<100$ \\
\hline \multicolumn{5}{|c|}{ Ecobrick $^{\circledR}$ material made with sludge from biological WWTP in Gava and clay (El Papiol) } \\
\hline 0 & 0.054 & $<0.001$ & $<0.1$ & $<0.1$ \\
\hline 15 & 0.055 & $<0.001$ & $<0.1$ & $<0.1$ \\
\hline \multicolumn{5}{|c|}{ Ceramic material with paper industry sludge } \\
\hline 0 & 0.054 & 0 & $<25$ & $<100$ \\
\hline 15 & 0.095 & 0 & $<25$ & $<100$ \\
\hline Allowed limit value of the test & 1 & 0.1 & $<25$ & $<100$ \\
\hline
\end{tabular}

concentrations of these elements are below their $U_{1}$ limits, so that the material is suitable for use in building without restrictions.

Outgassing and offgassing tests applied to these ceramic pieces have given negative results in all cases (see Table 5). Always well below the limits for a material that could be installed inside a manned spacecraft. In the case of ceramic pieces made with physico-chemical WWTP sludge, WLM values have been always lower than $10 \%$ of their limit value. It is noted that concentration values remain practically the same as for ceramic pieces made of $100 \%$ clay.

\section{Discussion}

Sludge concentrations higher than $25 \%$ in ceramic matrix would result in insufficient mechanical properties (cardboardlike consistency and irregular shape) for use as structural brick (Devant et al., 2011). There is also frequent that "Dandelion" flaws, typical from a poor plasticity of the raw mixture, appear. However, this material could be used for other purposes, such as ceramic thermal insulators.

Clearly, the discussion focuses on the presence of heavy metals whenever organic matter contributed by the sludge and clays themselves are completely destroyed due to the high sintering temperatures $\left(980-1050{ }^{\circ} \mathrm{C}\right)$.

Mixing and extrusion of clay-sludge mixture are essential to achieve an appropriate plastic green matter to avoid the formation of segregate agglomerates without possibility to encapsulate them within the vitreous matrix of the ceramic product.

Any possible migration of heavy metals from the metals contained in sludge to environment would only be determined by their solubility. Then, environmental quality of the ceramic pieces is guaranteed because the concentration of metals in the extractant (water), even in extreme conditions, does not exceed the $U_{1}$ limits allowed. This result has also pointed out by other authors (Liew et al., 2004). Even in the case of using galvanic sludges with a high burden of heavy metals, quantities of toxic elements in eluates remain below the regulation limits (see last rows of Table 4). This suggests that inclusion of sludges in ceramic matrices is a good alternative for inerting hazardous wastes (Ferreira et al., 1999).

It can be argued that the presence of sludge increases the capacity of inerting heavy metals in several cases in comparison with ceramic made of $100 \%$ clay. Maybe the combustion of organic matter intimately mixed clays increases the temperature locally which could favor the inclusion of heavy metals in a crystal lattice. In conclusion, our results confirm that these materials contain heavy metals that are toxic and hazardous but do not leach, as stated by Chang et al. (2007).

From the results shown in Table 4 we can deduce that there are no remarkable differences between the types of sludge used in the preparation of ceramic pieces. In any case, type of clay seems to have a higher incidence in leaching. In this sense the concentrations of $\mathrm{Ba}, \mathrm{Cr}, \mathrm{Pb}$, and $\mathrm{Ag}$ in eluates remain constant at any formulation of bricks $(10,20,30$, etc. per cent of sludges). There are just slight variations in the case of $\mathrm{Cd}$ and As, but always below the allowed limits. In some cases, addition of sludge is beneficial for inerting heavy metals from the same clay.

Inerting capacity of structural ceramics ("clay bricks") comes from the partial vitrification of the mineral components in the ceramic matrix that includes most of heavy metals. As shown in Table 4, some metals seem to have mobility, mainly $\mathrm{V}$ and to a lesser extent $\mathrm{Cr}$ and Mo. These elements are present in the phyllosilicates of clays as this mobility appears in ceramic pieces made with $100 \%$ clay and are therefore not attributable to the presence of sludge in their composition. Only in the case of $\mathrm{Cr}$ and Mo to a lesser extent, it could be attributed to the addition of sludge.

Through the Toxicity Leaching Characteristics Procedure (US EPA Method 1311), Weng et al. (2003) reported small concentrations of $\mathrm{Cr}$ and $\mathrm{Zn}$, which have not been here observed probably because we have used another type of extraction according to the NEN 7345 test.

These results make this alternative more environmentally friendly than, for instance, the direct use of sludge in agriculture. The latter presents problems for excessive content of $\mathrm{Cr}$ and $\mathrm{Cd}$, and also only a portion of the leached metals is easily assimilated by soils questioning its bioviability for a continuous application (Fuentes et al., 2004). Other authors have found increased concentrations of $\mathrm{Cu}, \mathrm{Ni}, \mathrm{Zn}$ and $\mathrm{Pb}$ in soils where sludge had been added with a clear downward trend from the first month after disposal. This suggests to establish limitations for its uncontrolled use (Kruse and Barrett, 1985).

Inerting alternatives for building products can be found in the formulation of cements and mortars that incorporate sewage sludges. In this sense, applying the norm NEN 7345, it can also be found that there are no environmental constraints to these materials even though the concentration of chloride is high when the mix includes $\mathrm{CaCl}_{2}$ as a reaction accelerator. In this case their leaching values are obviously higher than in ceramic materials and are located between $U_{1}$ and $U_{2}$ limits, even in what refers to the presence of sulfates in eluates formed during the hydration of the mixture (Valls and Vázquez, 2002). Comparatively, it is clear that concrete acts as a retardant to the diffusion of contaminants by encapsulating it, 
while ceramic allows a permanent immobilization of contaminants. The latter is more resistant to acid attack and therefore more suitable for use as construction material, because the higher the formation temperature, the greater the inerting of heavy metals (Suzuki et al., 1997).

Industrial use of incinerated bottom ashes in ceramic matrices has leaching behavior of one or two orders of magnitude with regard to that of sewage sludges, because the compounds that incorporate have lost reactivity in the formation of ceramic body. If sludges contain quantities of pollutants exceeding certain limits, such as $4 \%$ arsenic (As), a dangerous leaching can be produced (Mahzuz et al., 2009). In this case the resulting ceramic materials could lead to contamination levels of heavy metals, hence their use should be carefully regulated from the environmental point of view (Fujimori et al., 2004).

In short, the parameters that most influence the inerting process, are, in order of importance: (1) type of clay, (2) relative amount of sludge in the mixture, (3) calcination temperature, and (4) state of agglomeration of the piece. The reaction between sludge and ceramic clays is the dominant mechanism of encapsulation of sludges (in vitreous phase) (Magalhaes et al., 2004).

There is a general concern about problems related to the odor, gases and particles that eventually these ceramic products might emit when they are used to build buildings. However, the rigorous tests of outgassing ESA PSS-01-702 and offgassing ESA PSS-01-729 have allowed to show the complete absence of such problems. These tests can ensure the inert and harmless nature of these ceramic products and therefore there is not any environmental constraint for their widespread use. Unfortunately, the results obtained from these tests could not be compared with other works, as literature in this regard is not easy to be found.

\section{Conclusions}

Findings obtained from this study, which was based on the classical extruded or pressed raw materials for brick construction materials, show that the sludge can be successfully incorporated into bricks with sludge additions ranging from $5 \%$ to $25 \%$ in weight (and even more if we do not consider mechanical properties). The fired final product is red due to ferric-ferrous salts contained in raw materials (clays and sludges). It is also lighter and with more thermal and acoustical insulating properties than conventional clay bricks.

From the results presented in this paper and from the perspective of potential users of housing made with these materials, it can be concluded:

(1) Contents of sludge included in structural ceramics seems to have no influence on the environmental characteristics of these products. Then, they could be used as building material without restrictions other than the regulations of technical conditions that building materials must meet in each country.

(2) Leaching tests according to the standards NEN 7345, ESA PSS-01-702 and ESA PSS-01-729 show that there are no environmental restrictions on the use of clay bricks made with sewage sludges from either biological treatment, physico-chemical or paper industries.

(3) There were no significant variations depending on the type of clays and/or source of WWTP sludges. This suggests that the process of inerting sludge on clay bricks could be used without adverse effects on the health of users of the final products. Problems linked with the production process have not been the subject of this study related to clean production.
(4) In addition, no significant differences are observed in the concentrations of heavy metals in the eluates obtained from ceramic pieces with different contents of sewage sludges. In fact, there are no quantitative differences with regard to eluates from pieces made of $100 \%$ clay.

(5) The enormous productive capacity of the ceramic industry is a huge potential for incorporating sewage sludges from WWTP in the industrial process. Taking into account that the nominal production of clay bricks in a typical mediumsized ceramic company is higher than 200 tons per day, it could daily consume 30 tons of sewage sludges, which are generated at a medium WWTP in one day.

It is therefore concluded that, if the industrial production of clay bricks that include sewage sludge becomes a reality, the end user should know that there is no environmental restriction or any health risk in their use.

\section{References}

Alleman, J.E., Berman, N.A., 1984. Constructive sludge management: Biobrick. Journal of Environmental Engineering 110 (2), 301-311.

Almeida, M.I.A., Amaral, M.R., Sousa Correia, A.M., Fonseca Almeida, M., 1997. Ceramic building materials: an alternative in disposal of sewage sludge. Key Eng. Materials 132-136, 2280-2284.

Chang, F.-C., Lo, S.-L., Lee, M.-Y., Ko, C.-H., Lin, J.D., Huang, S.-C., Wang, C.-F., 2007. Leachability of metals from sludge-based artificial lightweight aggregate. Journal of Hazardous Materials 146, 98-105.

Cusidó, J.A., Cremades, L.V., González, M., 2003. Gaseous emissions from manufactured with urban sewage sludge during firing process. Waste Management 23, 273-280.

Devant, M., Cusidó, J.A., Soriano, C., 2011. Custom formulation of red ceramics with clay, sewage sludge and forest waste. Applied Clay Science 53, 669-675.

ESA PSS-01-702, 1994. A thermal vacuum test for the screening of space materials, European Space Agency.

ESA PSS-01-729, 1991. The determination of off-gassing products from materials and assembled articles to be used in a manned space vehicle crew compartment. Issue 1. European Space Agency.

Ferreira, J.M., Alves, H.M., Mendoça, A.M., 1999. Inertization of galvanic sludges by its incorporation in ceramic bricks. Boletín de la Sociedad Española de Cerámica y Vidrio 38 (2), 127-131.

Fuentes, A., Llorens, M., Sáez, J., Soler, A., Aguilar, M.I., Ortuño, J.F., Messeguer, V.F., 2004. Simple and sequential extractions of heavy metals from different sewage sludges. Chemosphere 54, 1039-1047.

Fujimori, E., Minamoto, M., Iwata, S., Chiba, K., Haraguchi, S., 2004. Enrichment of elements in industrial waste incineration bottom ashes obtained from three different types of incinerators, as studied by ICP-AES and ICP-MS. Journal of Material Cycles and Waste Management 6 (1), 73-79.

Kruse, E.A., Barrett, G.W., 1985. Effects of municipal sludge and fertilizer on heavy metal accumulation in earthworms. Environmental Pollution Series A, Ecological and Biological 38 (3), 235-244.

Liew, A.G., Idris, A., Samad, A.A., Wong, H.K., Jaafar, M.S., Baki, A.M., 2004. Reusability of sewage sludge in clay bricks. Journal of Material Cycles and Waste Management 6 (1), 41-47.

Lin, D.-F., Weng, C.-H., 2001. Use of sewage sludge ash as brick material. Journal of Environmental Engineering 10 (127), 922-927.

Magalhaes, J.M., Silva, J.E., Castro, F.P., Labrincha, J.A., 2004. Effect of experimental variables on the inertization of galvanic sludges in clay-based ceramics. Journal of Hazardous Materials 106, 139-147.

Mahzuz, H.M.A., Alam, R., Alam, M.N., Basak, R., Islam, M.S., 2009. Use of arsenic contaminated sludge in making ornamental bricks. International Journal of Environmental Science and Technology 6 (2), 291-298.

Montero, M.A., Jordan, M.M., Hernández-Crespo, M.S., Sanfeliu, T., 2009. The use of sewage sludges and marble residues in the manufacture of ceramic tile bodies. Applied Clay Science 46, 404-408.

NEN 7345, 1993. Determination of the release of inorganic characteristics of inorganic constituents from construction materials and stabilized waste products, NNI Delft (Netherlands). Formely Draft NEN 5432.

NEN 7375, 2004. Leaching characteristics of granular building and waste materials. The determination of availability of inorganic components for leaching: the Tank Test. Environment Agency, UK.

REACH, 2006. Regulation (EC) No 1907/2006 of the European Parliament and of the Council of 18 December 2006 concerning the Registration, Evaluation, Authorisation and Restriction of Chemicals (REACH).

Suzuki, S., Tanaka, M., Kaneko, T., 1997. Glass-ceramic from sewage sludge ash. Journal of Materials Science 7 (32), 1775-1779.

Valls, S., Vázquez, E., 2002. Leaching properties of stabilised/solidified cementadmixtures-sewage sludges systems. Waste Management 22, 37-45.

Van der Sloot, H.A., 2005. European activities on harmonization of leaching/ extraction test and standarisation in relation to the use of alternative materials in construction. URL: <http://www.leaching.net>. Access: 10 Mar. 2010. 
Weng, C.-H., Lin, D.-F., Chiang, P.-C., 2003. Utilization of sludge as brick materials. Advances in Environmental Research 7 (203), 679-685.

WHO, 2011. World Health Organization. URL: <http://www.who.int/gho/phe/en/ index.html> (Accessed: nov. 2011).
Wiebusch, B., Ozaki, M., Watanabe, H., Seyfried, C.F., 1998. Assessment of leaching tests on construction material made with incinerator ash (sewage sludge) Investigations in Japan and Germany. Water Science Technology 38 (7), 195205. 